\title{
Ring Opening of Spiroepoxides Dithianedioxide with Bis-nucleophiles
}

\author{
Ritmaleni $^{{ }^{*}}$ and V. K. Aggarwal ${ }^{2}$ \\ ${ }^{1}$ Department of Pharmaceutical Chemistry,Faculty of Pharmacy, Universitas Gadjah Mada, Sekip \\ Utara, Jogjakarta 55281, Indonesia \\ ${ }^{2}$ School of Chemistry, University of Bristol, Cantocks Close, Bristol, BS8 1TS, UK
}

Received 28 December 2010, accepted in final revised form 20 June 2011

\begin{abstract}
This research was aimed to apply the spiroepoxide dithianedioxide for the synthesis of amino acid via ring opening of the spiroepoxide by bis-nucleophiles. First attempt was made to synthesize the bis-nucleophiles, amino alcohol, which was eventually used to the ring opening reaction of the spiroepoxide to produce the morpholine ring compound. The reaction was carried out in racemic and asymmetric method with moderate yield and high 99\%. The last step produced amino acid that was still remained unsuccessful. However, it cannot be concluded yet whether the spiroepoxide dithianedioxide is the right intermediate for the synthesis of amino acid.
\end{abstract}

Keywords: Amino alcohol; Morpholine ring; Spiroepoxide dithianedioxide; Amino acid.

(c) 2011 JSR Publications. ISSN: 2070-0237 (Print); 2070-0245 (Online). All rights reserved.

doi: $10.3329 /$ jsr.v3i3.6746

J. Sci. Res. 3 (3), 575-586 (2011)

\section{Introduction}

Spiroepoxide dithianedioxides [1] has been successfully synthesised in only one diastereomeric form [2]. These novel structures can potentially be used in the synthesis of some important biologically active compounds, such as aza $\beta$-lactams and diaminopimelic acids. This spiroepoxide $\mathbf{1}$ has been succesfully applied to the synthesis of racemic [3] and asymmetric [4] aza $\beta$-Lactams.
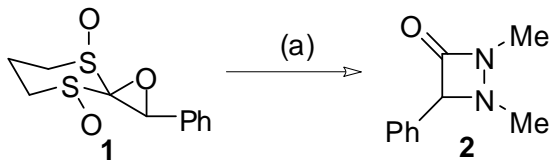

Scheme 1. Reagents and conditions: (a) MeNHNHMe $2 \mathrm{HCl}, \mathrm{NEt}$, THF, r.t., 24 h, $40 \%$.

\footnotetext{
*Corresponding author: ritmaleni@ymail.com
} 
The ring opening of epoxide 1a with bis-nuclephiles can also be applied to the synthesis of diaminopimelic acid and this work has been submitted for publication [5].<smiles>N[C](CCC[C@H](N)C(=O)O)C(=O)O</smiles>

Fig. 1. DAP structure.

Using a bis-nucleophilic moiety with different reactivity has been described in the ring opening of epoxide $\mathbf{1}$. In this case the more reactive nucleophilic substituent should ring open the epoxide, and then the other less reactive nucleophile should react in an intramolecular fashion. One of the examples involved the addition of $(R, R)$ pseudoephedrine to 1a [6], leading to two diastereomeric products, 4 and 5 which were obtained in a diastereomeric ratio of 8:1.

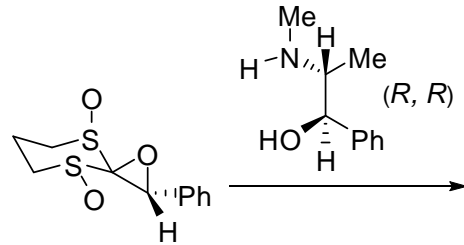

1<smiles>CC1C(c2ccccc2)OC(=O)C([PH+])[C@H]1c1ccccc1</smiles>

4

Major<smiles>CC1C(c2ccccc2)OC(=O)[C@@H](c2ccccc2)N1C</smiles>

5

8:1 mixture of diastereomers

Scheme 2. Ring opening of epoxide by ephedrine.

This research was aimed to apply this method to the ring opening of epoxide $\mathbf{1}$ with the amino alcohol, 2-amino-2,2-diphenylethanol 6 [7]. The nitrogen nucleophile would be expected to open $\mathbf{1}$ before the hydroxy group reacts with the activated carbonyl group, resulting in formation of the morpholine derivative 7 (Scheme 3).

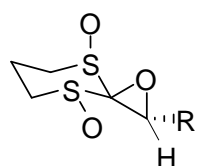

1<smiles></smiles>

6

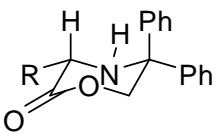

7

Scheme 3. Ring opening of epoxide by an amino alcohol.

\section{Material and Method}

\subsection{Synthesis of 2-Amino-2,2-diphenyl ethanol 6 [7]}

$\alpha$, $\alpha$-Diphenyl glycine $\left(4.09 \mathrm{mmol}, 930 \mathrm{mg}\right.$ ) was added to a stirred suspension of $\mathrm{LiAlH}_{4}$ (16.36 mmol, $620 \mathrm{mg}$ ) in dry THF (45 mL). The reaction mixture was heated to reflux at 
$80^{\circ} \mathrm{C}$ for $6 \mathrm{~h}$. After cooling down, $\mathrm{KOH}\left(56 \mathrm{mg}\right.$ in $0.5 \mathrm{~mL} \mathrm{H}_{2} \mathrm{O}$ ) was added and $5 \mathrm{~min}$ later $\mathrm{H}_{2} \mathrm{O}(1.0 \mathrm{~mL})$ was added. The reaction mixture was heated to reflux for $2 \mathrm{~h}$ and filtered through celite. The solvent was evaporated under vacuum. The crude product was recrystalized from DCM/hexane to yield 6 as a white crystalline product (636 mg, $73 \%$ ), $\mathrm{R}_{f}\left(10 \% \mathrm{EtOH} / \mathrm{CHCl}_{3}\right)$ 0.25, m.p 118-123 ${ }^{\circ} \mathrm{C}$ (DCM/hexane) (Found: C, 78.5; H, 6.8; N, 6.2; $\mathrm{C}_{14} \mathrm{H}_{15} \mathrm{NO}$ requires C, 78.8; H, 7.0; N, 6.5 [7] C, 78.7, H, 7.0]); $v_{\max }(\mathrm{KBr}) / \mathrm{cm}^{-1} 3343$ $(\mathrm{N}-\mathrm{H}), 3052(\mathrm{O}-\mathrm{H}), 2830(\mathrm{C}-\mathrm{H}), 1589(\mathrm{C}-\mathrm{OH}), 1493\left(-\mathrm{NH}_{2}\right), 1289(\mathrm{C}-\mathrm{N}), 1052\left(\mathrm{CH}_{2}-\right.$ $\mathrm{OH}) ; \delta_{\mathrm{H}}\left(270 \mathrm{MHz} ; \mathrm{CDCl}_{3}\right) 2.15\left(3 \mathrm{H}, \mathrm{s}, \mathrm{NH}_{2}\right.$ and $\left.-\mathrm{OH}\right), 4.10\left(2 \mathrm{H}, \mathrm{m},-\mathrm{CH}_{2}\right), 7.28-7.38$ $(10 \mathrm{H}, \mathrm{m}, \mathrm{Ph}) ; \delta_{\mathrm{C}}\left(68 \mathrm{MHz} ; \mathrm{CDCl}_{3}\right) 62.4(\mathrm{~s}), 70.3(\mathrm{t}), 126.8$ (2d), 126.9 (4d), $128.4(4 \mathrm{~d})$, 146.0 (2s); m/z (CI) 214 (M+ + 1); (79), 197 (99), 182 (100), 136 (27).

\subsection{General procedure for the synthesis of the diphenylmorpholine compounds}

Amino alcohol 6 (0.82 mmol, $175 \mathrm{mg})$ in DCM (2 mL) was added to a solution of epoxide $1(0.68 \mathrm{mmol})$ in DCM (2 mL) was added. The reaction mixture was stirred at reflux for 24-28 h, finally the solvent was removed under reduced pressure.

2.2.1. Synthesis of (3RS)-5, 5-triphenylmorpholin-2-one 9a using epoxide 1 (0.68 mmol, $175 \mathrm{mg}$ ).

The reaction mixture was evaporated off under reduced pressure. Flash column chromatography (100\% $\mathrm{CHCl}_{3}$ ) yielded a white solid. Recrystallization from $\mathrm{DCM} /$ hexane gave 9a as a white crystalline solid (88 mg, $39 \%$ ), $\mathrm{R}_{f}\left(100 \% \mathrm{CHCl}_{3}\right)$ 0.4, m.p. 135-136 ${ }^{\circ} \mathrm{C}$ (DCM/hexane) (Found: C, 80.2; H, 6.0; N, 4.4 $\mathrm{C}_{22} \mathrm{H}_{19} \mathrm{~N} \mathrm{O}_{2}$ requires C, 80.2; H, $5.8 \mathrm{~N}, 4.3) ; v_{\max }(\mathrm{KBr}) / \mathrm{cm}^{-1} 3291(\mathrm{NH}), 1722(\mathrm{C}=\mathrm{O}) ; \delta_{\mathrm{H}}\left(270 \mathrm{MHz} ; \mathrm{CDCl}_{3}\right) 2.59$ (1H, dd, ${ }^{3} J$ 5.6, $\left.{ }^{4} J 2.9, \mathrm{NH}\right), 4.44\left(1 \mathrm{H}, \mathrm{d},{ }^{3} J 5.6,3-\mathrm{H}\right), 4.74\left(1 \mathrm{H}, \mathrm{d},{ }^{2} J 11.5,6-\mathrm{H}_{\mathrm{ax}}\right), 5.03$ (1H, dd, ${ }^{2} J$ 11.5, ${ }^{4} J$ 2.9, 6- $\left.\mathrm{H}_{\mathrm{eq}}\right), 7.28-7.55(15 \mathrm{H}, \mathrm{m}, \mathrm{Ph}) ; \delta_{\mathrm{C}}\left(68 \mathrm{MHz} ; \mathrm{CDCl}_{3}\right) 60.3(\mathrm{~s})$, 61.7 (d), 75.4 (t), 126.8 (d), 127.5 (d), 127.9 (d), 128.1 (d), 128.5 (d), 128.6 (d), 128.7 (d), 129.4 (d), 168.4 (s); m/z (EI) 329 (M+5 55), 285 (43), 180 (100).

2.2.2. Synthesis of (3S)-5, 5-triphenylmorpholin-2-one 9a using epoxide (+)-1 (0.27 mmol, $69 \mathrm{mg}$ )

The reaction mixture was stirred and refluxed for $24 \mathrm{~h}$. Flash column chromatography $\left(100 \% \mathrm{CHCl}_{3}\right)$ yielded a white solid. Recrystallisation from DCM/hexane gave 9a as a white crystalline solid (29 mg, $32 \%$ ), $96 \%$ ee by HPLC, with identical ${ }^{1} \mathrm{H}-\mathrm{NMR}$ and ${ }^{13} \mathrm{C}$ NMR to racemic material; $[\alpha]_{\mathrm{D}}^{23}-21.1$ (c. 0.18 in $\mathrm{CHCl}_{3}$ ).

2.2.3. Synthesis of (3RS)-phenethyl-5, 5-diphenylmorpholin-2-one $9 b$ using epoxide $1 b$ (0.09 $\mathrm{mmol}, 26 \mathrm{mg}$ )

The reaction mixture was stirred and refluxed for $24 \mathrm{~h}$. Flash column chromatography $\left(100 \% \mathrm{CHCl}_{3}\right)$ yielded a white solid. Recrystallization from DCM/hexane gave $\mathbf{9 b}$ as a 
white crystalline solid (21.3 mg, $66 \%$, $\mathrm{R}_{f}\left(100 \% \mathrm{CHCl}_{3}\right)$ 0.4, m.p. $147-148^{\circ} \mathrm{C}$ (DCM/hexane) (Found: C, 80.3; H, 6.5; N, $3.9 \mathrm{C}_{24} \mathrm{H}_{23} \mathrm{NO}_{2}$ requires C, 80.6; H, $6.5 \mathrm{~N}$, 3.9); $v_{\max }(\mathrm{KBr}) / \mathrm{cm}^{-1} 3303(\mathrm{NH}), 1728(\mathrm{C}=\mathrm{O}), 1164(\mathrm{C}-\mathrm{O}) ; \delta_{\mathrm{H}}\left(400 \mathrm{MHz} ; \mathrm{CDCl}_{3}\right) 1.73$ $(1 \mathrm{H}, \mathrm{s}, \mathrm{N}-\mathrm{H})$ 2.08-2.18 (1H, m, 7-H), 2.27-2.36 (1H, m, 7-H), 2.82-2.95 (2H, m, 8-H), 3.38 (1H, dd, $J$ 7.3, 4.0, 3-H), 4.62 (1H, d, $J 11.9,6-\mathrm{H}), 4.82$ (1H, d, $J 11.9$, 6-H), 7.18$7.37(15 \mathrm{H}, \mathrm{m}, \mathrm{Ph}) ; \delta_{\mathrm{C}}\left(100 \mathrm{MHz} ; \mathrm{CDCl}_{3}\right) 32.0(\mathrm{t}), 33.7$ (t), $53.9(\mathrm{~d}), 61.3(\mathrm{~s}), 70.4(\mathrm{t})$, 126.0 (d), 126.6 (d), 127.2 (d), 127.9 (d), 128.1 (d), 128.6 (d), 128.9 (d), 141.0 (s), 141.7 (s), 143.7 (s), 170.8 (s); m/z (EI) 357 (M+3 30), 266 (28), 208 (90), 180 (100), 165 (68), 91 (58).

2.2.4. Synthesis of (3S)-Phenethyl-5, 5-diphenylmorpholin-2-one 9b using epoxide (+)$1 \mathrm{~b}(10.56 \mathrm{mmol}, 3.0 \mathrm{~g})$

The reaction mixture was stirred at reflux for $24 \mathrm{~h}$ and then the solvent was removed under reduced pressure. Flash column chromatography (100\% $\mathrm{CHCl}_{3}$ ) yielded the morpholine compound $\mathbf{9 b}$. Recrystallization from DCM/hexane gave $\mathbf{9 b}$ as a white crystalline solid (1.57 g, $42 \%$ ), $99 \%$ ee by HPLC, showing identical ${ }^{1} \mathrm{H}-\mathrm{NMR}$ and ${ }^{13} \mathrm{C}$ NMR to racemic material; $[\alpha]_{\mathrm{D}}^{23}-163.6$ (c. 1.0 in $\mathrm{CHCl}_{3}$ ).

\subsection{General procedure for the synthesis of the phenylmorpholine compounds}

Method A:

$(R)-(-)-2-P h e n y l g l y c i n o l ~(0.47 \mathrm{mmol}, 64.5 \mathrm{mg})$ in DCM (2 mL) was added to a solution of epoxide (+)-1 $(0.39 \mathrm{mmol})$ in DCM $(2 \mathrm{~mL})$. The reaction mixture was stirred at reflux for $24 \mathrm{~h}$ and finally the solvent was removed under reduced pressure.

\section{Method B:}

(S)-(+)-2-Phenylglycinol (1.13 mmol, $155 \mathrm{mg})$ in DCM $(15 \mathrm{~mL})$ was added to a solution of epoxide (+)-1 (0.94 mmol). The reaction mixture was stirred and refluxed for $21 \mathrm{~h}$. The solvent was then removed under reduced pressure.

\subsubsection{Synthesis of (3S), (5R)-Diphenylmorpholin-2-one 20a}

Method A, using epoxide (+)-1 (2.02 mmol, $523 \mathrm{mg})$ : Flash column chromatography (100\% $\mathrm{CHCl}_{3}$ ) yielded 20a as a colourless oil (55 mg, $11 \%$, $\mathrm{R}_{f}\left(100 \% \mathrm{CHCl}_{3}\right)$ 0.25, $v_{\max }(\mathrm{KBr}) / \mathrm{cm}^{-1} 3314(\mathrm{NH}), 1734(\mathrm{C}=\mathrm{O}) 1185(\mathrm{C}-\mathrm{O}) 1290(\mathrm{C}-\mathrm{N}) ; \delta_{\mathrm{H}}\left(400 \mathrm{MHz} ; \mathrm{CDCl}_{3}\right)$ $2.23(1 \mathrm{H}, \mathrm{s}, \mathrm{NH}), 4.40\left(1 \mathrm{H}, \mathrm{dd}, J\right.$ 8.3, 4.3, 6- $\left.\mathrm{H}_{\mathrm{eq}}\right) 4.43\left(1 \mathrm{H}, \mathrm{dd}, J\right.$ 8.3, 8.1, 6- $\left.\mathrm{H}_{\mathrm{ax}}\right), 4.46(1 \mathrm{H}$, dd, $J$ 8.1, 4.3, 5-H), 4.93 (1H, s, 3-H), 7.28-7.40 (10H, m, Ph); $\delta_{\mathrm{C}}\left(100 \mathrm{MHz} ; \mathrm{CDCl}_{3}\right) 57.8$ (d), 64.2 (d), 75.0 (t), 127.2 (2d), 128.5 (2d), 128.6 (2d), 128.8 (2d), 129.0 (2d), 137.8 (s),

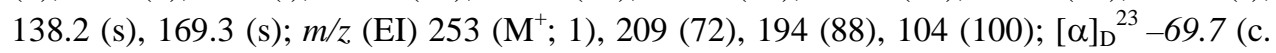
4.7 in $\mathrm{CHCl}_{3}$ ) 


\subsubsection{Synthesis of (3S)-Phenethyl-(5R)-phenylmorpholin-2-one 20a}

Method A, using epoxide (+)-1b (0.45 mmol, $128 \mathrm{mg})$ : The reaction mixture was stirred and refluxed for $21 \mathrm{~h}$. Flash column chromatography (100\% $\mathrm{CHCl}_{3}$ ) yielded a white solid that was recrystallized from DCM/hexane to obtain 20a as a white crystalline solid (30.4 mg, $24 \%$ ), $\mathrm{R}_{f}\left(100 \% \mathrm{CHCl}_{3}\right)$ 0.19, m.p. 80 ${ }^{\circ} \mathrm{C}(\mathrm{DCM} / \mathrm{hexane}) ; v_{\max }(\mathrm{KBr}) / \mathrm{cm}^{-1} 3342(\mathrm{~N}-$ $\mathrm{H}), 1739(\mathrm{C}=\mathrm{O}) 1122(\mathrm{C}-\mathrm{O}) 1301(\mathrm{C}-\mathrm{N}) ; \delta_{\mathrm{H}}\left(400 \mathrm{MHz} ; \mathrm{CDCl}_{3}\right) 1.87(1 \mathrm{H}, \mathrm{s}, \mathrm{NH}), 2.16-$ 2.25 (1H, m, 7-H), 2.28-2.37 (1H, m, 7-H), 2.79-2.92 (2H, m, 8-H), 3.80-3.86 (1H, m, 3H), 4.22 (1H, dd, $\left.J 10.3,2.2,6-\mathrm{H}_{\mathrm{eq}}\right) 4.26\left(1 \mathrm{H}, \mathrm{dd}, J 10.3,9.0,6-\mathrm{H}_{\mathrm{ax}}\right), 4.38(1 \mathrm{H}, \mathrm{dd}, J 9.0$, 2.2, 5-H), 7.28-7.40 (10H, m, Ph); $\delta_{\mathrm{C}}\left(100 \mathrm{MHz} ; \mathrm{CDCl}_{3}\right) 31.8(\mathrm{t}), 34.8(\mathrm{t}), 57.4(\mathrm{~d}), 58.3$ (d), 74.8 (t), 126.2 (d), 127.1 (d), 128.5 (2d), 128.6 (2d), 128.7 (2d), 128.9 (2d), 138.0 (s), 140.6 (s), 169.8 (s); ( $\mathrm{M}^{+}$, Found 281.1422. $\mathrm{C}_{18} \mathrm{H}_{19} \mathrm{O}_{2} \mathrm{~N}$ requires 281.1416) $\mathrm{m} / \mathrm{z}$ (EI) 281 $\left(\mathrm{M}^{+}\right.$; 17), 237 (19), 132 (51), 104 (100); $[\alpha]_{\mathrm{D}}{ }^{23}-91.2$ (c. 0.86 in $\mathrm{CHCl}_{3}$ )

\subsubsection{Synthesis of 3(S)-Phenethyl-5(S)-phenyl-morpholin-2-one $21 b$}

Method B, using epoxide (+)-1b (0.94 mmol, $268 \mathrm{mg})$ : Flash column chromatography $\left(100 \% \mathrm{CHCl}_{3}\right)$ yielded $\mathbf{2 1 b}$ as a white solid recrystallized from DCM/hexane, (76 mg, 29 \%), $\mathrm{R}_{f}\left(100 \% \mathrm{CHCl}_{3}\right)$ 0.25, m.p. 118-121 ${ }^{\circ} \mathrm{C}$ (DCM/hexane); $v_{\max }(\mathrm{KBr}) / \mathrm{cm}^{-1} 3342(\mathrm{NH})$, $1739(\mathrm{C}=\mathrm{O}) 1122(\mathrm{C}-\mathrm{O}) 1301(\mathrm{C}-\mathrm{N}) ; \delta_{\mathrm{H}}\left(400 \mathrm{MHz} ; \mathrm{CDCl}_{3}\right) 1.79(1 \mathrm{H}, \mathrm{s}, \mathrm{NH}), 2.06(1 \mathrm{H}$, ddt, $J$ 14.1, 8.8, 5.9, 7-H), 2.36 (1H, ddt, $J$ 14.1, 7.3, 4.8, 7-H), 2.79-2.92 (2H, m, 8-H), $3.73(1 \mathrm{H}, \mathrm{m}, 3-\mathrm{H}), 4.26$ (1H, dd, $\left.J 10.7,10.3,6-\mathrm{H}_{\mathrm{ax}}\right) 4.38$ (1H, dd, $J 10.3$, 4.4, 5-H), 4.45 $\left(1 \mathrm{H}, \mathrm{dd}, 10.7,4.4,6-\mathrm{H}_{\mathrm{eq}}\right), 7.28-7.40(10 \mathrm{H}, \mathrm{m}, \mathrm{Ph}) ; \delta_{\mathrm{C}}\left(100 \mathrm{MHz} ; \mathrm{CDCl}_{3}\right) 32.1(\mathrm{t}), 33.4(\mathrm{t})$, 53.4 (d), 54.1 (d), 77.5 (t), 126.2 (d), 126.8(d), 128.3 (2d), 128.5 (2d), 128.6 (2d), 128.9 (2d), 138.5 (s), 140.8 (s), 171.5 (s); ( $\mathrm{M}^{+}$, Found 281.1412. $\mathrm{C}_{18} \mathrm{H}_{19} \mathrm{NO}_{2}$ requires 281.1416) m/z (EI) 281 (M+1 17), 237 (19), 132 (51), 104 (100); $[\alpha]_{\mathrm{D}}{ }^{23}-32.5$ (c. 1.0 in $\mathrm{CHCl}_{3}$ ).

\subsubsection{Synthesis of (4S)-Methyl-(3S)-phenethyl-5-phenylmorpholin-2-one 25}

The morpholin $21 \mathbf{b}$ (0.11 mmol, $31 \mathrm{mg})$ was dissolved in methanol (10 mL). Palladium hydroxide (33 mg) and trifluoroactic acid ( $55 \mu \mathrm{L}$ ) was added to the stirred solution. The resultant mixture was stirred under hydrogen at room temperature for $18 \mathrm{~h}$. Filtration of the solvent through celite and evaporation under reduced pressure yielded a residue. Flash column chromatography ( $5 \% \mathrm{MeOH} / \mathrm{CHCl}_{3}$ ) of the residue gave 25 as a yellow oil (21 mg, $65 \%), \mathrm{R}_{f}\left(5 \% \mathrm{MeOH} / \mathrm{CHCl}_{3}\right)$ 0.35; $v_{\max }(\mathrm{KBr}) / \mathrm{cm}^{-1} 3431(\mathrm{NH}), 1733(\mathrm{C}=\mathrm{O}) 1173$ (C-O) $1454(\mathrm{C}-\mathrm{N}) ; \delta_{\mathrm{H}}\left(400 \mathrm{MHz} ; \mathrm{CDCl}_{3}\right)$ 1.82-1.97 (2H, m, 7-CH $)$, 2.58-2.70 (2H, m, 8$\left.\mathrm{CH}_{2}\right), 3.23(1 \mathrm{H}, \mathrm{t}, J 5.4,3-\mathrm{H}), 3.38\left(3 \mathrm{H}, \mathrm{s}, \mathrm{N}-\mathrm{CH}_{3}\right), 3.50\left(1 \mathrm{H}, \mathrm{dd}, J 10.8,8.3,6-\mathrm{H}_{\mathrm{ax}}\right) 3.59$ (1H, dd, $J$ 10.8, 4.4, 6- $\left.\mathrm{H}_{\mathrm{eq}}\right), 3.64(1 \mathrm{H}, \mathrm{dd}, 8.3,4.4,5-\mathrm{H}), 7.09-7.27(10 \mathrm{H}, \mathrm{m}, \mathrm{Ph}) ; \delta_{\mathrm{C}}(100$ $\left.\mathrm{MHz} ; \mathrm{CDCl}_{3}\right) 31.8$ (t), 34.8 (t), 51.7 (q), 58.9 (d), 63.5 (d), $66.1(\mathrm{t}), 126.1$ (d), 127.3 (d), 127.8 (2d), 128.4 (2d), 128.5 (2d), 128.6 (2d), 140.5 (s), 141.3 (s), 175.3 (s); m/z (EI) 295 (M+1), 282 (100), 254 (20), 222 (7), 132 (24), 117 (21), 104 (33), 91 (85); 


\section{Results and Discussions}

\subsection{Synthesis of the amino alcohol 6}

Synthesis of the amino alcohol that would be required for the ring opening of epoxide 1 was carried out following the Newman procedure, [7] and involved the reaction of 2amino-2,2-diphenyl-carboxylic acid 8 in THF with the reducing agent $\mathrm{LiAlH}_{4}$ to yield amino alcohol 6 in good yield (Scheme 4).

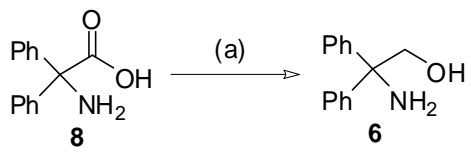

Scheme 4. Reagents and conditions: (a) $\mathrm{LiAlH}_{4}$, THF, reflux, $73 \%$.

In parallel with these studies, we needed to establish which nucleophile was to be employed in the ring opening of the spiro-epoxide to allow ready access to the amino acid moiety. It was decided to investigate amino alcohols in which the amino group was $\alpha$ to an aryl group so that deprotection could be effected.

A solvent study was realised for the reaction of amino alcohol $\mathbf{6}$ with epoxide $\mathbf{1}$ (Scheme 5). The reactions were carried out with six different aprotic solvents. The best yield was obtained when $\mathrm{CH}_{2} \mathrm{Cl}_{2}$ was used as the solvent. When DMF was used, no expected product was formed, only decomposition products were observed by TLC (Table 1).

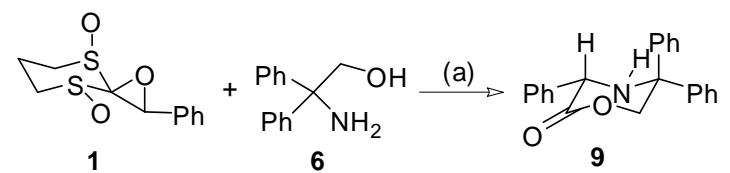

Scheme 5. Reagents and conditions: (a) solvents, r.t, 3 days.

Table 6. Effect of solvent.

\begin{tabular}{ccc}
\hline Entry & Solvent & Yield (\%) $^{\mathrm{a}}$ \\
\hline 1 & DCM & 42 \\
2 & Toluene & 29 \\
3 & THF & 18 \\
4 & Acetonitrile & 17 \\
5 & Dioxane & 2 \\
6 & DMF & - \\
\hline
\end{tabular}

a : yield calculated by ${ }^{1} \mathrm{H}-\mathrm{NMR}$ analysis of crude material using dibenzylether as an internal standard. 
Due to the slow rate of reaction, the mixture was heated in an attempt to shorten the reaction time from 3 days to 24 hours, using DCM as solvent. The reaction conditions were applied to both the racemic and enantiopure epoxides 1 . The reaction gave the product in moderate yield and excellent ees (Scheme 6).
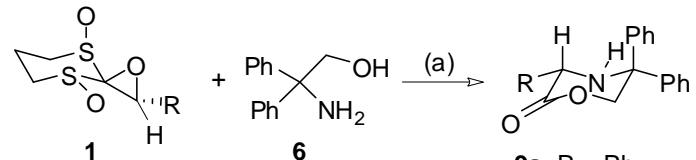

9a, $\mathrm{R}=\mathrm{Ph}$

9b, $\mathrm{R}=\mathrm{CH}_{2} \mathrm{CH}_{2} \mathrm{Ph}$

Scheme 6. Reagents and conditions: (a) $\mathrm{CH}_{2} \mathrm{Cl}_{2}$, reflux, 24 h (9a, $32 \%, 96 \%$ ee; 9b, $66 \%$, $99 \%$ ee).

It is assumed that no epimerisation of the $\alpha$-keto intermediate occurred during the reaction, but for $\mathbf{1}$ with $96 \%$ ee, a small amount of epimerisation may have occurred in intermediate $\mathbf{1 1 .}$

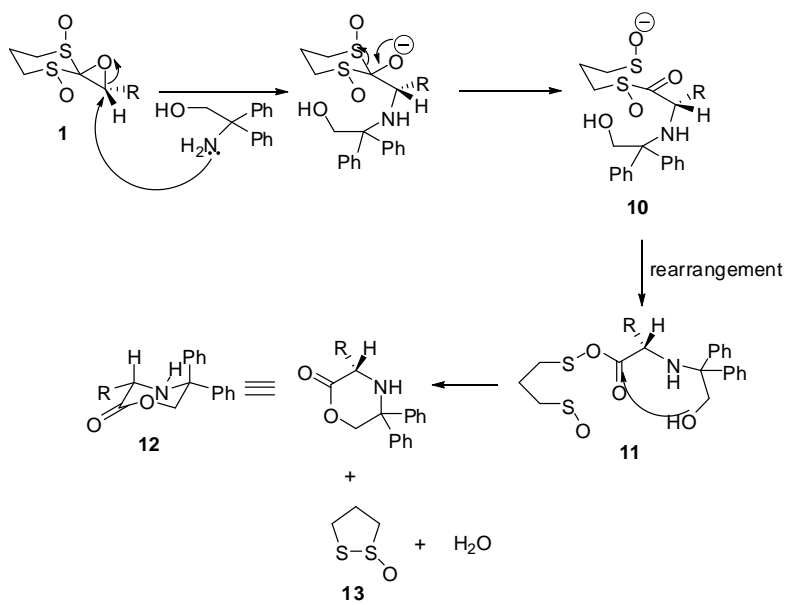

Scheme 7. Proposed mechanism of epimerisation.

The next reaction involved cleavage of the $\mathrm{C}-\mathrm{N}$ bond, and hydrolysis of the ester group to release the amino acid $\mathbf{1 4}$ (Scheme 8).

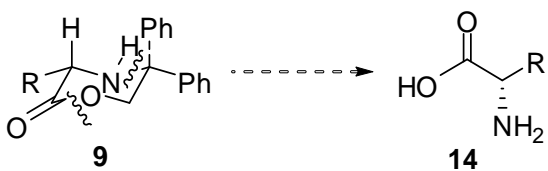

Scheme 8. Target molecule 14. 
In order to carry out this, morpholine $\mathbf{9}$ was subjected to various conditions (a-g), but none gave the amino acid $\mathbf{1 4}$. Instead, the reactions generated the protonated product (a, $d$ and g) [8], starting material (f) [9, 10, 11, 12], decomposition of starting material (b) [13] or some unidentifiable compounds (c and e) [14].

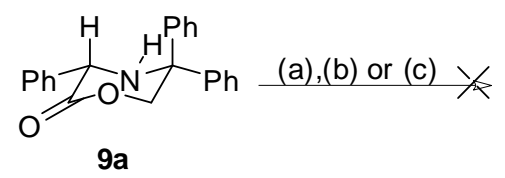<smiles>N[C@@H](C(=O)O)c1ccccc1</smiles>

Scheme 9. Reagents and Conditions: (a) TFA, $\mathrm{Et}_{3} \mathrm{SiH}, \mathrm{CH}_{2} \mathrm{Cl}_{2}, 5^{\circ} \mathrm{C}$, r.t to reflux; (b) $\mathrm{Me}_{3} \mathrm{SiBr}$, $\mathrm{CH}_{2} \mathrm{Cl}_{2}$, r.t.; (c) $\mathrm{PdCl}_{2}$ (0.7 eq.), $\mathrm{H}_{2}$ (50 psi), THF, $24 \mathrm{~h}$.

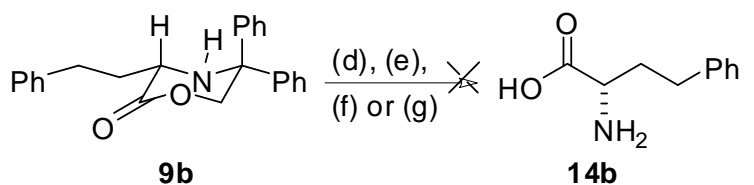

Scheme 10. Reagents and conditions: (d) TFA, r.t.; (e) $\mathrm{PdCl}_{2}$ (0.7 eq.), $\mathrm{H}_{2}$ (50 psi), THF, 24 h; (f) 10 $\mathrm{mol} \% \mathrm{Pd} / \mathrm{C}, \mathrm{NH}_{4} \mathrm{OCOH}, \mathrm{MeOH}$, r.t; (g) TFA, $\mathrm{Et}_{3} \mathrm{SiH}$, r.t.

It was assumed, from the above results, that the C-N bond was too strong to be cleaved. To make this bond weaker, attempts were made to introduce electron-withdrawing groups on the nitrogen of the morpholine compound 9. Reactions were done to protect the nitrogen with either a Boc-group or TFA-group [15] or acetate-group [16] but none of them could be formed and only the starting material was recovered in each case.<smiles>O=C1OC(c2ccccc2)C(CCc2ccccc2)NC1c1ccccc1</smiles>

$9 b$

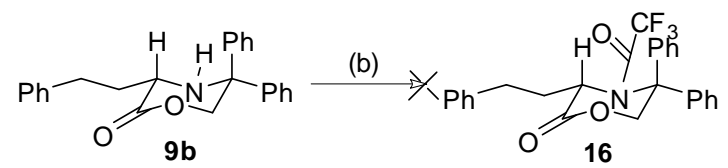

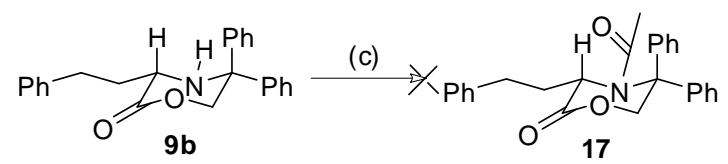

Scheme 11. Reagents and conditions: (a) $\mathrm{Boc}_{2} \mathrm{O}$, DMAP, THF; (b) TFAA, DMAP, py, THF; (c) Zn, $\mathrm{HCl}$, toluene, MeCOCl. 
Considering the results obtained, we could conclude that the morpholine compound $\mathbf{9}$ was too hindered and it was impossible to cleave the $\mathrm{C}-\mathrm{N}$ bond or to perform reactions on nitrogen.

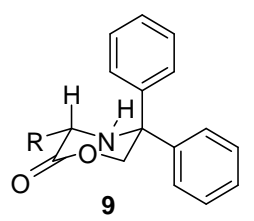

We envisaged on the opening of the epoxide with an amino alcohol containing only one phenyl group in order to reduce the steric hindrance. This would hopefully result in easier $\mathrm{C}-\mathrm{N}$ bond cleavage of the morpholine moiety. Epoxide 1 ring was opened using commercially available (R)-(-)-2-amino-glycinol 18 and (S)-(+)-2-amino-glycinol 19 in DCM at room temperature to give low yields of $\mathbf{2 0}$ and $\mathbf{2 1}$ as single diastereomers (Scheme 12).

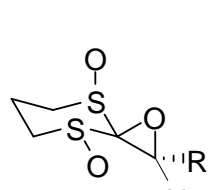

1
$\mathrm{H}$ (a)

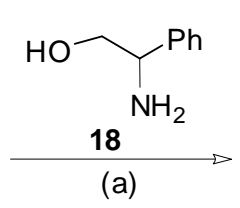

20a, $\mathrm{R}=\mathrm{Ph}$

20b, $\mathrm{R}=\mathrm{CH}_{2} \mathrm{CH}_{2} \mathrm{Ph}$

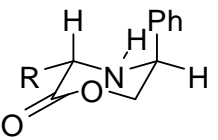

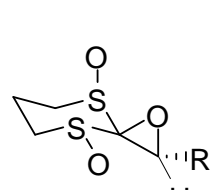

1

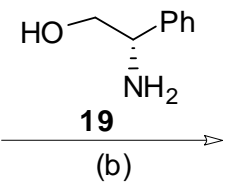

(b)

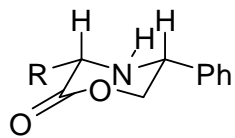

21a, $\mathrm{R}=\mathrm{Ph}$

21b, $\mathrm{R}=\mathrm{CH}_{2} \mathrm{CH}_{2} \mathrm{Ph}$

Scheme 12. Reagents and conditions: (a) $\mathrm{CH}_{2} \mathrm{Cl}_{2}$, r.t., 24 h (20a, 11 \%; 20b, 27 \%); (b) $\mathrm{CH}_{2} \mathrm{Cl}_{2}$, r.t., 24 h, (21a, 0 \%; 21b, 29 \%).

In this study, problems arose in the reaction between epoxide 1 and (S)-(+)-2-aminoglycinol 19. TLC monitoring showed weak spots of the product, but it was hard to tell from ${ }^{1} \mathrm{H}-\mathrm{NMR}$ if only a single diastereomer was formed because there appeared to be many impurities in the reaction mixture, making structural assignment very difficult.

There was concern about the enantioselectivities of products $\mathbf{2 0}$ and $\mathbf{2 1}$ as it was assumed that if a single diastereomer formed it could be assumed that only one enantiomer was obtained because there is no epimerisation of the (R)-(-)-2-amino-glycinol 
18 or $(S)-(+)-2$-amino-glycinol 19 was possible. Epimerisation would only occur in the $\alpha$ keto intermediate $\mathbf{2 4}$ before the second nucleophilic attacked (Scheme 13).

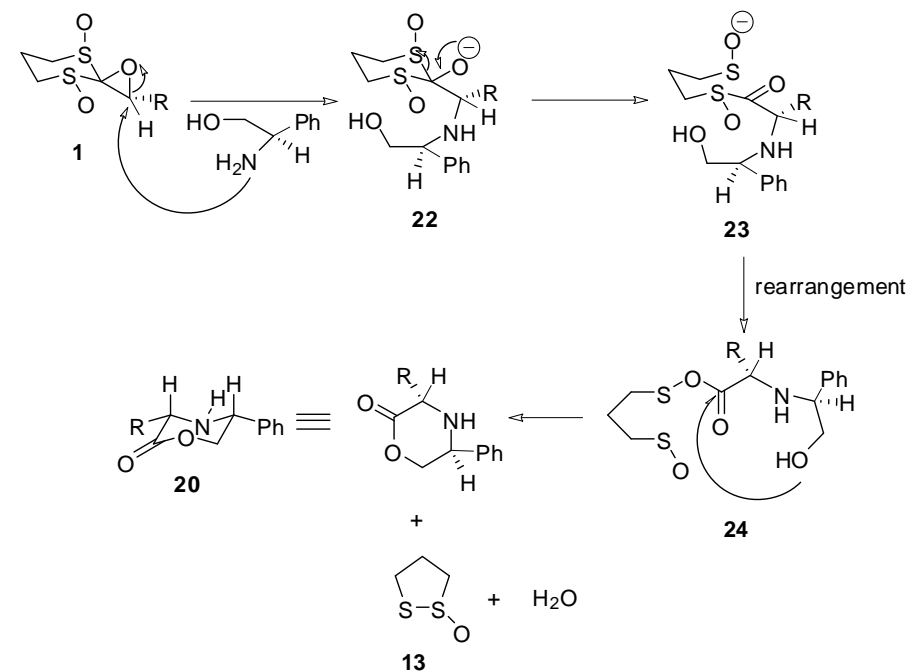

Scheme 13. Proposed mechanism.

Harwood [17] used hydrogenation to cleave the C-N bond in similar morpholine rings and this condition was applied to our substrate.

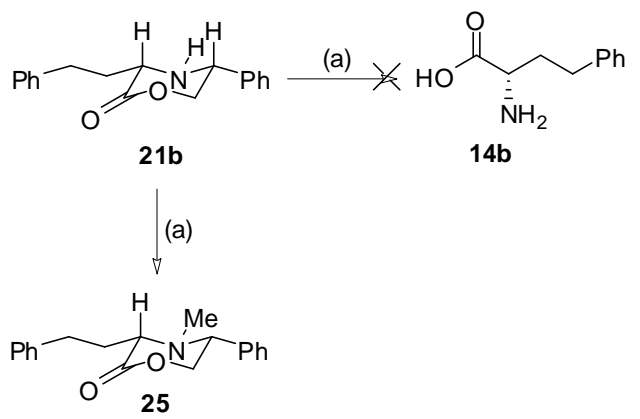

Scheme 14. Reagents and conditions: (a) $\mathrm{H}_{2}, \mathrm{Pd}(\mathrm{OH})_{2} / \mathrm{C}, \mathrm{MeOH}$, r.t., 18 h, $65 \%$.

However, the hydrogenation reaction of morpholine compound 21b did not give a good result. The only product that formed was the nitrogen-methylated product $\mathbf{2 5}$. This was assumed to be due to the reaction of palladium with methanol $\mathbf{2 6}$, formed formaldehyde insitu, which reacted with $\mathbf{2 1 b}$ to form iminium salt $\mathbf{2 8}$. Hydrogenation only gave $\mathbf{2 5}$ in 33 $\%$ yield. The outcome was surprising as very similar system (Scheme 14) had been reduced uneventfully by Harwood. Although the reduction could have been conducted in a different solvent to avoid this allylation, neither time nor material was available. 

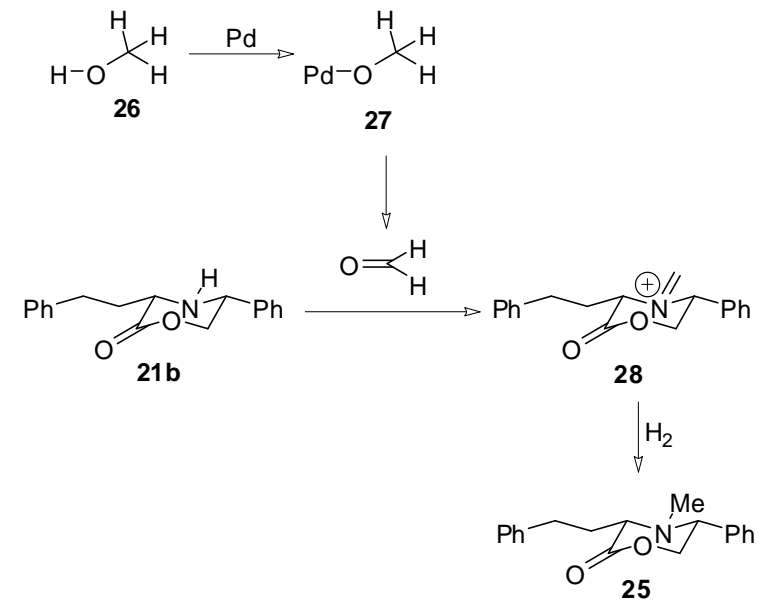

Scheme 15. Proposed mechanism of formation of methylated-product 25.

\section{Conclusion}

The ring opening of epoxide $\mathbf{1}$ has demonstrated that these epoxides can be used to synthesize enantiomerically and diastereomerically pure morpholine compounds 19, 20 and 21. Due to the steric hindrance of 19, it is difficult to conclude at this stage whether spiroepoxide is an appropriate intermediate for the synthesis of the amino acids and furthermore, diaminopimelic acid.

\section{Acknowledgment}

We thank QUE Project of the Faculty of Pharmacy, Gadjah Mada University, Indonesia for funding.

\section{References}

1. Ritmaleni, Ph.D. Thesis, School of Chemistry University of Bristol, Bristol, UK (2004).

2. V. K. Aggarwal, R. M. Steel, Ritmaleni, J. K. Barrel, I. Grayson, J. Org. Chem. 68, 4087 (2003). http://dx.doi.org/10.1021/jo034032r

3. Ritmaleni and V. K. Aggarwal, Proc. Int. Semi. on Chem. (Jatinangor Indonesia, 2008), p. 211.

4. Ritmaleni and V. K. Aggarwal, Proc. of Semi. Nat. Farmasi dan Pameran Kesehatan (Bandung Indonesia, 2009).

5. Ritmaleni and V. K. Aggarwal, submitted for publication (2011).

6. J. K. Barrell, Ph.D. Thesis, Department of Chemistry, The University of Sheffield, UK (1999).

7. M. S. Newman and W. M. Edwards, J. Am. Chem. Soc. 76, 1840 (1954). http://dx.doi.org/10.1021/ja01636a031

8. L. A. Carpino, H-G. Chao, S. Ghassemi, E. M. E. Mansour, C. Riemer, R. Warrass, D. SadatAalaee, G. A. Truran, H. Imazumi, A. El-Faham, D. Ionescu, M. Ismail, T. L. Kowaleski, C. H. Han, H. Wenschuh, M. Bayermann, M. Bienert, H. Shroff, F. Albericio, S. A. Triolo, N. A. Sole and S. A. Kates, J. Org. Chem. 60, 7718 (1995). http://dx.doi.org/10.1021/jo00129a005 
9. M. Brands, , R. Endermann, R. Gahlmann, J. Kruger, S. Raddatz, J. Stoltefub, V. N. Belov, S. Nizamov, V. V. Sokolov, and A. de Meijere, J. Med. Chem. 45, 4246 (2002). http://dx.doi.org/10.1021/jm0111191

10. A. Mehta, R. J. Jaouhari, T. J. Benson, and K. T. Douglas, Tetrahedron Lett. 33, 5441 (1992). http://dx.doi.org/10.1016/0040-4039(93)88013-9

11. W. L. Neumann, M. M. Rogic, and T. J. Dunn, Tetrahedron Lett. 32, 5865 (1991). http://dx.doi.org/10.1016/S0040-4039(00)79412-3

12. E. D. Cox, L. K. Hamaker, J. Li, P. Yu, K. M. Czerwinski, L. Deng, D. W. Bennett, J. M. Cook, W. H. Watson, and M. Krawiec, J. Org. Chem. 62, 44 (1997). http://dx.doi.org/10.1021/jo951170a

13. P. L. Ornstein, J. Org. Chem. 54, 2251 (1989). http://dx.doi.org/10.1021/jo00270a045

14. G. Sui, P. Kele, J. Orbulescu, Q. Huo, and R. M. Leblanc, Lett. Peptide Sci. 8, 47 (2001). http://dx.doi.org/10.1007/BF02443578

15. P. T. Lansbury, T. E. Nickson, J. P. Vacca, R. D. Sindelar, and J. M. Measingerll, Tetrahedron 43, 5583 (1987). http://dx.doi.org/10.1016/S0040-4020(01)87739-5

16. H. M. Meshrama, G. S. Reddy, M. M. Reddy, and J. S. Yadav, Tetrahedron Lett. 39, 4103 (1998). http://dx.doi.org/10.1016/S0040-4039(98)00666-2

17. A. S. Anslow, L. M. Harwood, H. Phillips, D. Watkin, and L. F. Wong, Tetrahedron: Asymmetry 2, 1343 (1991). http://dx.doi.org/10.1016/S0957-4166(00)86146-7 